\title{
Naming and exploring the causes of collective violence against African migrants in post-apartheid South Africa: Whither Ubuntu'?
}

\author{
MODASSAH
}

\begin{abstract}
In South Africa, attacks mainly directed at black non-South Africans, is a rampant, longstanding phenomenon notwithstanding the spirit of Ubuntu which is thought to permeate the social fabric. Assumptions have been made in various labels describing the attacks, raising concerns about their appropriateness. Further, various explanations and hypotheses have been advanced about causes of or reasons for the attacks. The root causes of the attacks need to be properly understood for lasting solutions to be found. The objectives of this article are: first, to analyse the appropriateness of various labels in order to name the phenomenon South Africa is confronted with; and, secondly, to identify the root causes of the attacks. This analysis could assist in formulating policies and strategies to address the attacks. This article is theoretical, and it draws on in-depth analysis of relevant literature and empirical studies in order to addresses two research questions. First, are the attacks motivated by pure criminality, or are they manifestations of Afro-phobia/Negrophobia, expressions of xenophobia or indicators of outright racism? Secondly, what are the causes of or explanations for the attacks? On nomenclature, the article rejects the criminality label as reductionist. To an extent, the Afro-phobia/Negrophobia label has merit, but the racism tag is unsustainable. Xenophobia emerges as the appropriate description because empirical studies point to a significant number of South Africans holding xenophobic attitudes and having expressed their preparedness to forcefully eject foreign nationals. The article concludes that xenophobia is a complex phenomenon and has multiple causes, which must be properly understood and that finding effective solutions to it requires involvement of all key stakeholders.
\end{abstract}

Keywords: Xenophobia; Afro-phobia; Negrophobia; Ubuntu; South Africa

\section{Introduction}

"Xenophobia “ derives from the Greek words “xenos “, meaning stranger' or "foreigner” and "phobos", "fear" and literally, it refers to irrational or unreasonable fear and dislike of strangers or people thought to be foreign (Davis, 2010: 8). The literature indicates a plethora

1. Ubuntu is a Zulu word meaning spirit of compassion and caring for others. It is a universal African concept that underlines several principles ranging from manners to humanity, including: fairness, compassion, honesty, trustworthiness, putting community interest above one's own, helping others, respect for human dignity and caring for each other's well-being, among others. In Xhosa, Ubuntu is expressed as Umntu ngumntu ngabanye abantu, which means "People are people through other people" or "I am human because I belong to the human community and I view and treat others accordingly". Ipi Ubuntu? literally means "where is the compassion, the caring about others?"

2 Faculty of Business \& Management Sciences, Cape Peninsula University of Technology, P.O. Box 652, Cape Town, 8 000, South Africa, E-mail: dassahm@cput.ac.za

Td The Journal for Transdisciplinary Research in Southern Africa, 11(4), December 2015, Special edition, 
of definitions of xenophobia, a few of which are examined to highlight their essence. Bekker (2010: 127) defines xenophobia as "the deep dislike of non-nationals by nationals of a recipient state". For Petros, Airhihenbuwa, Simbayi, Rawlangan \& Brown (2006: 74), xenophobia is: "attitudes, prejudices and behaviours that exclude and vilify others because they are considered to be outsiders or foreigners to the community, society or national identity". Crush \& Ramachandran (2009 cited in Davis, 2010: 8) define xenophobia as: "highly negative perceptions and practices that discriminate against non-citizen groups on the basis of their foreign origin or nationality." The sense that xenophobia is simply an attitude or a state of mind is unmistakable in these definitions. Although they are clear, in the South African context, the definitions are academic and have little practical usefulness as they fail to take into account the consequences of the attitudes of dislike, fear and hatred. In other words, they fail to capture the practice of xenophobia, which involves, among other things, invented tension and violence, destruction of property, hostility and abuse, often leading to death, directed specifically at black, African migrants by black South Africans in what might be called the Cain-Abel phenomenon. This reality of xenophobia, the lived experiences of black, African migrants, is different from attitudes such as dislike, fear and hatred that constitute the academic definitions. Consequently, within the South African context and for the purposes of this article, xenophobia has to be broadly understood to be more than dislike, fear and hatred. It involves violent physical action: beating, burning, ejection and displacement, dispossession, dehumanisation and loss of human dignity, killing, looting, rape, torture and other forms of violence that constitute the experience of African migrants.

In post-apartheid South Africa, violence by black South Africans against non-South Africans, mostly blacks from other African countries, is not a new phenomenon. According to Misago, Landau \& Monson (2008: 8), since the country's liberation from the clutches of apartheid in 1994, "hundreds of people have been attacked or killed because of their status as outsiders or non-citizens." Although some of the attacks have been directed at migrant entrepreneurs, dubbed "violent entrepreneurship" (Charman \& Piper, 2012: 86), there are instances of attacks on black foreign nationals not involved in any business. The literature indicates unanimity that black foreign nationals have been objects of attack over the years. However, it points to differences among politicians and researchers in naming the attacks phenomenon and providing explanations or causes.

The article addresses two key questions. First, are the attacks acts of pure criminality, as politicians and government officials would have us believe; manifestations of Afrophobia/Negrophobia (on account of their being primarily perpetrated by black South Africans against their counterparts from other African countries), expressions of xenophobia (the fact that they are specifically directed at foreigners) or outright racism (discrimination against others based on perception of their inferiority)? Naming the character and significance of an act, rather than disguising it under false labels, misnaming or using false language to hide its reprehensibility, is an important step in acknowledging its existence. It is essential the specific social ill represented by the attacks be named if appropriate solutions are to be devised. The second research question has to do with why the attacks happened: what are the causes or explanations and hypotheses advanced for the attacks? This question is asked so that the root cause(s) of the social ill, rather than its manifestations or symptoms, can be addressed directly. Structurally, the article is organised in six sections. Section one, the introduction, outlines the etymology, defines the term "xenophobia" and acknowledges that xenophobia is a global phenomenon and not a typically an African or South Africa malaise. Section two discusses the international dimension of xenophobia by calling up xenophobic 
incidents in African countries and globally. Section three provides an insight into the incidence of attacks against foreigners in South Africa specifically, while Section four discusses labels used to characterise the attacks phenomenon in South Africa. The fifth section examines causes of xenophobia, explanations, intellectual framings and hypotheses put forward by scholars. Section six, the conclusion, proposes collaboration between the South African government and key stakeholders to stem the tide of xenophobia.

\section{Xenophobia: International, African and South African contexts}

\section{International context}

Xenophobia exists in both the global North and South, in democratic and totalitarian states alike in violent and non-violent forms and may be government-sanctioned or carried out by groups/collections of individuals. That xenophobic attacks against refugees, asylum seekers and migrants occur globally is attested to by the following incidents. According to Human Rights First (HRF, 2011: 19), in May 2011, right-wing groups attacked Asians and Africans in Italy. Further, one hundred and eighty-six assaults and 18 murders, ostensibly attributed to racism or xenophobia, occurred between January 2007 and July 2009 in Italy, most of the victims being immigrants and refugees. The organisation also indicates that between 2003 and 2007, attacks against Hispanics or people from Latin America, increased by almost 40\%, declined in 2008 and 2009 and rose by 10\% in 2010. Hate crimes motivated by racism and religious intolerance are generally committed against refugees (HRF, 2011:14). Citing Rasario (2009), the HRF (2011: 17) presents a picture of Haitian refugees, migrants and stateless persons of Haitian origin being assaulted and killed in the Dominican Republic. In India, racism towards people of African decent is common: Burmese Chin and Somali refugees have faced attacks (HRF, 2011: 18). HRF (2011: 23) also states that migrants and refugees from Burma living in Thailand experience xenophobic attitudes from the population and suffer violence from government-sanctioned groups and ordinary people. Migrants from Central Asian countries are victims of racist and ethnically-motivated Russian neo-Nazi skinheads (HRF, 2011: 21). Similarly, Burmese migrants and refugees have been long-standing victims of violent attacks and killings by government security forces and agents and individual citizens in Thailand (HRF, 2011: 23), a situation similar to the experience of Burmese refugees and migrants in Malaysia who endure xenophobic attitudes from the population and violence from a government-sanctioned group and ordinary citizens (HRF, 2011: 20). In the Ukraine, xenophobic attacks and harassment have been targeted at refugees, asylum seekers and migrants, culminating in murders between 2006 and 2008. In 2011, violent attacks were reported against dark-skinned foreigners (HRF, 2011: 24).

A study, White Papers of Hate (2013), focusing on incidents that took place in 2012 and 2013, indicates high levels of xenophobia, ultra-nationalism, anti-Semitism and hate crimes perpetuated against religious minorities and immigrants in 19 European countries. Ranked from high to low levels of xenophobia, ultra-nationalism, anti-Semitism and hate crimes, the countries are: Greece, Latvia, Ukraine, Estonia, Maldova, Lithuania, United Kingdom, Hungary, France, Russia, Bulgaria, Romania, Poland, Czech Republic, Italy, Finland, Germany, Albania and Croatia. The study found that in Russia, for example, half the population in big cities expressed support for the slogan "Russia for Russians". According to Pollmann (2015), xenophobia is prevalent in Japan. Following a July 8 deadline for permanent residents to switch from aliens registration cards to new residence cards, a rumour came up to the effect that failure to switch would lead to loss of residence status and possible 
deportation. Consequently, there was a avalanche of calls, letters and emails went from ordinary Japanese citizens to the Immigration Bureau turning in their "illegal" Zainichi ethnic Koreans neighbours who, in fact, are legal residents.

\section{African context}

Xenophobia is rife in Africa and constitutes a powerful tool in the hands of politicians. Xenophobia has occurred in strong Pan-Africanist inspired countries such as Ghana and Nigeria that have been pioneering advocates of African unity since the 1960s. Two features of xenophobia in Africa are discernible. First, it tends to be black-on-black in nature, that is, violent action is often taken against or negative attitude exhibited towards other Africans who are non-citizens in what could be likened to the Cain-Abel (brother against brother) phenomenon. Secondly, violent action or attitude may be carried out by masses of citizens without the express blessings of government, as has happened in South Africa.

Perhaps, the first large-scale government-sanctioned xenophobia action in Africa was that of the Ghana government's Aliens Compliance Order of 1969, which saw the expulsion of migrants from other West African countries. The irony of this action cannot be lost on anyone with a good understanding of Pan-Africanism. Ghana gained independence in 1957, the first country in sub-Saharan Africa. In the 1960s, the country was an attractive destination for migrants mainly because the then President, Dr Kwame Nkrumah, a champion of Pan-Africanism, declared the country the home for all Africans. Consequently, the Nkrumah regime did not take any drastic measures to stem the tide of migration to Ghana by citizens of neighbouring countries. However, after the overthrow of Nkrumah in February 1966, the Progress Party government, faced with growing unemployment and a fall in the world price of cocoa (Aremu, 2014: 79), used the Aliens Compliance Order in 1969, to expel about 191000 foreigners mainly from Burkina Faso, Togo, Mali and Nigeria. In fact, most of them (140 000) were Nigerians.

Another major government-sanctioned xenophobic action occurred in 1983 in the form of Nigeria's well-calculated response to Ghana's 1969 Aliens Compliance Order. With the oil boom of the 1970s and Ghana's failing economy, many Ghanaians migrated to Nigeria. According to Aremu (2013: 14), in 1983, faced with declining oil revenue, a devalued currency and inflation, the Nigerian government revoked Articles 4 and 27 of the Protocol on Free Movement of Persons and Right of Residence and Establishment, which was ratified by member states of the Economic Community of West African States in 1980 and, using the medium of television, ordered more than a million unskilled foreigners living and working illegally and to leave the country in two weeks. Aremu (2013: 341) states that a number of reasons were offered to justify this action, including: ensuring integrity of immigration laws, reduced foreign exchange earnings occasioned by economic recession, involvement of some foreign nationals in violent religious disturbances and involvement of some Ghanaian nationals in criminal activities such as armed robbery. However, Aremu (2013: 341) notes that a covert reason for the expulsion was Nigerian policy-makers' frustration at not being able to use the platform of the Economic Community of West African States (ECOWAS) to assert the country's ambition of projecting its leadership of the West African sub-region.

The third large-scale government-sanctioned xenophobic incident was Idi Amin's 1972 decree expelling Asians from Uganda. According to Tumuhairwe (2012: n.p.), before Uganda gained independence, the British colonial administration had brought people of South Asian decent to work as clerks or unskilled/semiskilled manual labourers on construction sites and 
farms. Many Asians were also in the business of banking and tailoring and Asians constituted $80 \%$ of doctors, lawyers and teachers. The growing prominence of Indians in the economy prompted the establishment of a committee on "Africanisation of commerce and industry", which made proposals to limit the role of Indians in the economic and professional spheres. Owing to the Asians' distrust of President Milton Obote, many did not take up Ugandan citizenship, while some maintained their status as British-protected persons. Obote was overthrown by Idi Amin, who accused him of "over-concentrating on politics, at the expense of taking care of our economic life" (Tumuhairwe, 2012: n.p.).

Kersting (2009: 12) provides three instances where the governments of Congo Brazzaville and Zaire (now Democratic Republic of Congo) used xenophobia to their political advantage. First, a football match between Congo Brazzaville and Gabon in September 1962 sparked xenophobic violence. The second example is that of President of Zaire, Mobutu Sesekoko who, in 1972, granted citizenship to all migrants Burundian and Rwandese immigrants who had been living in the country since 1950. However, faced with national anti-immigrant sentiment, in 1981 a bill was introduced that attempted to redefine citizenship by stating that only people living 'on the soil' since 1885 (the year the Berlin Conference was held), which was now deemed to be the year of independence, qualified to be citizens. The second example cited by Kersting was the harnessing of anti-foreign propaganda by President Mobutu, which led to ethnic cleansing of Banyarwanda in North Kivu in 1993 and an attempt to expel Congolese Tutsis in 1996. Thirdly, according to Kersting (2009: 12), in September 1977, although Congolese themselves did not exhibit any xenophobic tendencies, 6000 West African migrants were deported by the government of Congo Brazzaville, while their shops and businesses were seized and given to citizens. This was followed by the enacting of legislation in 2005 forbidding foreigners, particularly West Africans, who are described as "ndingari", literally translated as "ticks sucking blood from the attached cattle", from engaging in small transport, baking and street-stall businesses.

\section{South African context}

That South Africans have strong negative attitudes towards foreigners in general, particularly black non-citizens, is indisputable. A South African Migration Project survey (SAMP, 2006) found strong indications of xenophobia: half of the participants (50\%) favoured deportation of foreign nationals, irrespective of legal status; three-quarters (75\%) were against increasing the number of refugees and a similar proportion (75\%) favoured the idea of containing refuges in border camps, instead of being integrated into society. Seven years later, in 2013, SAMP administered the same questions in a survey and found the following: half (50\%) of South Africans wanted foreigners to have their identity documents on them all the times; $63 \%$ would like to have the country's border fences electrified; $50 \%$ favoured migrants without proper documentation to be denied police protection; 41\% supported compulsory refugees' HIV testing; 30\% wanted a complete ban of migration to South Africa and 14\% thought all migrants enter the country in order to commit a crime. The 2006 and 2013 SAMP findings demonstrate a consistently negative attitude towards foreign nationals. In particular, the 2013 findings show further hardening of attitudes towards foreign nationals is discernible.

One of the earliest incidents of hostile action against African migrants occurred barely three years after attainment of democracy when, in August 1997, foreign street-traders were attacked in Johannesburg. In blatant disregard of the often-cited, honoured-in-words-thanin-deeds, philosophy of Ubuntu, violence against African migrants has been occurring over 
the years, culminating in the May 2008 country-wide attacks that resulted in more than 60 deaths, about 700 injured and more than 100000 internally displaced persons. The 2008 anti-foreigner violence erupted on 11 May in Alexandra, Johannesburg and in 16 days engulfed the whole country. The attacks have been described as the worst violence in South Africa since the end of apartheid (McKnight, 2008: 8) and, for the first time since 1994, troops were deployed to curb violence in the streets (McKnight, 2008: 18). The burning of a Mozambican, Ernesto Alfabeto Nhamuave, in a Johannesburg street casts a long, indelible shadow over the "rainbow nation". Unsurprisingly, but on a smaller scale, violent attacks on mainly black non-South Africans resurfaced in April 2015 in Durban, allegedly sparked by a statement that foreigners should go back to their countries because they are changing the nature of South Africa society with their goods and enjoying wealth that should have been for local people.

Adjai \& Lazaridis (2013: 195-196) cite a litany of incidents of attacks on foreigners, mostly black Africans: in 1998, three foreign nationals were thrown off a moving train in Pretoria; in 1998, a taxi driver beat up a Rwandan refugee on account of his being a foreigner; in 1999, the SABC reported the killing of 30 refugees and acid being poured on the body of one; in 2000, Zandspruit residents in Natal burnt down the shacks of Zimbabweans living there; in 2001, armed men threw a Sudanese refugee off a train in Pretoria and 22 migrants were reported to have been stabbed in Cape Town for no reason other being foreigners; in 2005, Zimbabwean and Somali refugees were beaten in Bothaville in the Free State; in 2006, Somali traders were driven out of a Knysna township and about 30 shops damaged; a month later, foreign-owned shops in the Western Cape were attacked and looted, resulting in the displacement of 40 foreigners who had to be sheltered in mosques and some by friends.

According to Crush \& Ramachandran (2014: 5), in August 1997, foreign street-traders were attacked and assaulted in Johannesburg resulting in loss of goods, "accompanied by angry and vitriolic anti-immigrant rhetoric". These earlier attacks were precursors to the May 2008 attacks that left 62 dead, 22 of whom were South Africans, and more than 150000 displaced (Adjai \& Lazaridis, 2013: 195). Misago et al. (2008: 5) add that "dozens of women were raped ... and property worth of millions of Rand looted, destroyed or taken over by local residents." Further, Misago et al. (2008: 24-25) provide an exhaustive list of recorded major xenophobic incidents between December 1994 and April 2008 characterised by violence.

\section{Features of xenophobia in South Africa}

An unmistakable feature of xenophobia in South Africa is its racial undertones. Black migrants, mostly from other African countries, including those from Southern African Development Community (SADC) member states, are victims of violence, while whites of any nationality are welcome (Solomon \& Kosaka, n.d.: 8). Neocosmos (2006) attributes this racially selective xenophobia to stereotyping of the stranger of African origin against the rather ironic fact that many African countries played an important role in defeating apartheid by providing sanctuary, education and sustenance to exiled South Africans who are today's political gatekeepers (Nyamnjoh, 2006).

Another feature is the lack of a typical profile of a xenophobic person who has strong negative attitudes irrespective of race, gender, education and socio-economic status (Crush, 2008: 4). Crush (2008: 15) states that: "xenophobic attitudes are widespread and entrenched 
in South Africa and not the preserve of a small (criminal) minority." This means that negative towards foreigners are not confined to any identifiable single group or groups. This poses a public education challenge (Solomon \& Kosaka, n.d.: 9). Although xenophobic attitudes are stronger among whites than blacks (Crush, 2008: 5), there is no recorded incident of whites attacking foreigners. According to Fauvelle-Aymar \& Segatti (2011: 75), the 2008 xenophobic violence occurred in local government wards that had: black residents, high proportion of men, many language groups, significant inequality and high proportion of people with intermediary income alongside poor groups, and higher proportion of informal settlements.

\section{Labeling the attacks}

The first research question posed is: are the attacks acts of criminality, manifestations of Afro-phobia/Negrophobia, expressions of xenophobia or outright racism? In the literature and empirical studies, the attacks are named in various ways. The orthodox position of xenophobia denialists (government, politicians, state officials, some researchers and political commentators) is that violent attacks against citizens of other African countries are acts of pure criminality committed by isolated, anti-social elements (Crush \& Ramachandran, 2014: 1). This has generated the "just crime/not xenophobia" discourse, which suggests those who attack foreigners are motivated by greed, not discriminatory sentiments. Others have even gone as far as proclaiming that: "South Africans are not xenophobic" (Polzer \& Takabvirwa, 2010: 6). According to Everatt (n.d.: 2), during his address at the national tribute in remembrance of the victims of attacks on foreign nationals in 2008, President Mbeki, among other things, said:

\section{Everything I know about my people tells me that these heirs to the teachings of Tiyo Soga, J.G. Xaba and Pixley Seme, the masses who have consistently responded positively to the Pan-African messages of the oldest liberation movement on our continent, the African National Congress, are not xenophobic.}

On 13 July 2010, the then Minister of Police emphatically stated that: "there is no such systematic thing as xenophobia in the country" and attributed the violence against foreigners to the activities of criminal elements, following the statement "these are not xenophobic attacks... but acts of criminality..." made by the South African Communist Party a few days earlier (Polzer \& Takabvirwa, 2010: 3). In April 2010, according to the authors, a police captain at Gamaskop police station in Mossel Bay referring to the 2008 attacks said:

\section{In our area it was ... more people that saw the opportunity to do housebreakings and especially at the businesses of foreigners and do it under the cover of xenophobia; so actually, although it was called xenophobia, it wasn't actually xenophobia in our area. We believe it was more criminal activities and not xenophobia as such....}

A statement such as this is symptomatic of a long-standing face-saving discourse to attribute violent attacks against mostly black non-citizens to crime (all countries have criminal elements, after all) that has taken root among some politicians and the South African Police Service. This argument is buoyed by the fact that in some specific cases, such as attacks against Somali spaza shop owners in Delft, a high level of criminality in the area and "violent entrepreneurship" (the link between business and crime and use of violence against economic opponents in emerging capitalist economies) have played a decisive role (Charman \& Piper, 2012: 86). Rather than confront the reality of xenophobia directly, xenophobia minimalists tend to blame laxity at South Africa's borders and see other issues such as lack of 
transformation and redistribution of wealth as a deeper problem, that is, competition for scarce resources (jobs, housing resources and public services), of which xenophobia is a symptom (Crush \& Ramachandran, 2014: 2).

Denial of the existence of xenophobia in South Africa is evident not only among politicians, but also academics, as the following extract shows:

As anthropologists, we are deeply concerned, both professionally and as citizens, that these actions reflect a continuing emphasis in South African political discourse on cultural, racial and national differences. It is a discourse that, drawing on a long discarded anthropology, essentialises such differences even as it claims to celebrate them. It is a discourse that was central to colonialism, slavery, segregation and apartheid. It is a discourse that perversely persists to the present, now manifesting in the way the media labels as "xenophobia" horrendously violent acts where some South Africans raise fists, swing axes and pangas, and use matches to light fires as means to attack their fellows who happen to speak different languages and allegedly look somewhat different from themselves (Sharp, 2008: 2).

Gqola (2008) and Mngxitama (2009) suggest the May 2008 attacks were manifestations of Afro-phobia or Negrophobia. Afro-phobia is defined as fear or dislike of Africans and their culture and could be associated with the attacks since they were mostly directed at migrants of African origin. Negrophobia refers to fear or dislike of black people in general and their culture. The fact that there are no reported incidents of white foreigners, some who are in the country illegally, and very few Asians being targets of violence (Bekker, 2010: 34) seems to lend some support for the attacks being labeled Afro-phobia or Negrophobia. Afro-phobia and Negrophobia are linked to "old" racism on the assumption that black citizens visiting violence on black foreigners is based on differentiation of the "other" (foreigner) on the grounds of degree of colour through the level of pigmentation. However, it is clear and as Davis (2010: 10) argues, that black foreigners are not targeted because they are of a different race, but because they are readily identifiable, by race, as foreigners.

Decades of enforced isolation, race-based urban migration control, designated group areas and creation of "bantustans" have made many South Africans foreigners in their own country (Dodson, 2010: n.d.) and strangers to their compatriots, generating bitterness among blacks, particularly. It is commonly assumed that racist views are held against people of other races. However, "racists dislike foreigners even if they are racially similar" (Mattes et al., 2009: 26). Tafira (2011: 115) rejects both Afro-phobia and Negrophobia as labels for the 2008 attacks and also rejects xenophobic label, preferring "new racism" to characterise the attacks on foreigners. The author argues that: "what happens in South Africa ... must be understood in the context of racism, practised by black people against other black people." Justifying rejection of the term "xenophobia", Tafira (2011: 115) explains that:

xenophobia has been the term the media has used, juggled around and fed to their audiences; it is possible that the media themselves do not understand the racial nature of anti-immigrant attacks; commentators who have used the term may have done so unconsciously and inadvertently or for lack of a better term to describe anti-immigrant practices in post-apartheid South Africa. I assume that it may be incomprehensible to many people that racism can be a practice between people of the same skin colour. Furthermore, I suspect commentators, the media included, may fail to see the New Racism, as it has unfolded, as an unfortunate misconception. They may fall into the common trap of understanding the conundrum of racism as mostly biology-based. They 
have not come to see how people of the same skin colour, in this case black African immigrants and black South Africans, are and have over the years been transformed into racialised subjects and how they have come to perceive each other in the light of their racial subjectivities.

The crux of Tafira's (2011: 115) argument is that apartheid racism, xenophobia and the new racism are different forms of racism, since "racism is a fluid, chameleonic and delicate term", the meaning of which changes in time. The author further argues that with the discrediting of biological conceptions of racial superiority and inferiority, the cultural aspects of racism take centre stage. Tafira (2011: 116) equates biological racism to classical or inegalitarian racism (the Other as inferior to be dominated and discriminated against) and cultural racism to differential racism (the "Other" as a new danger to society, threat or invader that must be kept at bay, expelled or destroyed).

While admitting that xenophobia could be linked to new racism as they share similarities, including perception of "... the other as a threat; discrimination and exclusion based on the other's cultural origin; and the implementation of policies that lead to the tightening of immigration controls", Adjai \& Lazaridis (2013: 193) contend that the two are distinctly different: racism involves the creation of rules, laws, regulations and institutions to support it such as existed during the apartheid era. For xenophobia, existing institutions are used to exclude others; they are not established for that purpose. Thus, while racism and xenophobia are related, they are different and cannot be used interchangeably. Adding the word "new" to "racism" does not alter the nature of racism, just as decorating a donkey does not make it a horse. Substituting "xenophobia" with "new racism" would justify exclusion of others and give racism not only a modern face, but also some respectability.

\section{Explaining the attacks}

Considering the second research question: why did the attacks happen - what are the causes, explanations or hypotheses? Dodson (2010: 5-7) provides six axes of explanations. The first are economic/material and pitched at two levels. At the first level, poor black South Africans perceive foreign blacks as competitors for jobs, housing and other resources. At the second level, wealthy black and white South Africans detest the idea of their tax money being used "to provide shelter and services to people seen to be pouring into South Africa to escape political incompetence and economic mismanagement further north" (Sharp, 2008: 2). The next set of explanations are social/socio-political in nature and posit that the end of apartheid and subsequent establishment of a non-racial national identity necessarily created a "nonSouth African" identity as an opposition "other", with this social position occupied by foreign Africans in South Africa. Cultural stereotyping is the third basis of explaining xenophobia. It is said that contact between South Africans and diverse immigrants after 1994 resulted in mutual stereotyping and exaggeration of cultural differences, leading to prejudice and antagonism. The next explanation for xenophobia is black South Africans' desire to protect their rights and benefits of citizenship from appropriation by non-citizens (Nyamnjoh, 2006), who may also be "illegal". This is held to account for anti-foreigner attitudes.

Further, a lack of political leadership has been blamed for producing and reproducing xenophobic attitudes among South Africans. Dodson (2010: 7) states that: "among senior government figures, right up to the three post-apartheid presidents, attitudes toward foreign Africans in South Africa have been at best ambivalent and occasionally downright negative." During his speech on National Day of Safety and Security in 1994, President Mandela is 
reported to have said: "the fact that illegal immigrants are involved in violent criminal activity must not tempt us into the dangerous attitude which regards all foreigners with hostility" (Dodson, 2010: 7), a statement with potential to encourage people to link foreigners not just with illegality, but also criminality. According to Misago et al. (2008: 18), in 1997, the then Minister of Defence, Joe Modise said:

\title{
As for crime, the army is helping the police get rid of crime and violence in the country. However, what can we do? We have one million illegal immigrants in our country who commit crimes and who are mistaken by some people for South African citizens. That is the real problem.
}

The final axis of explanation is not only outright denial, but also attribution of the attacks to "naked criminal activity", as President Mbeki's statement on 3 July 2008 makes clear:

\begin{abstract}
What happened during those days was not inspired by possessed nationalism, or extreme chauvinism, resulting in our communities violently expressing the bitherto unknown sentiments of mass and mindless hatred of foreigners - xenophobia .... I heard insistently that my people have turned or become xenophobic .... I wondered what the accusers knew about my people which I do not know. And this I must say - none in our society has any right to encourage or incite xenophobia by trying to explain naked criminal activity by cloaking it in the garb of xenophobia (Dodson, 2010: 7).
\end{abstract}

At a deeper level, Hågensen (2014: 12-39) discusses three broad groupings of explanations for xenophobia: socio-cultural, structural and institutional. Socio-cultural explanations encompass social identity theory, bi-cultural hypothesis and inherited culture. Social identity theory is based on two key assumptions: first, individuals strive to maintain or enhance their self-esteem; secondly, social groups and membership of these groups are associated with negative and positive feelings. Nationality and citizenship have assumed prominence since 1994. At the core of the bio-cultural hypothesis is the view that foreigners are targets of xenophobia because they can be easily identified. Inherited culture is identical to isolation hypothesis. It blames xenophobia on isolation of South Africa's different racial groups from each other and from the rest of the world, leading to the development of intolerance of differences.

Structural explanations, which have some connections with socio-cultural explanations, include relative deprivation theory, theory of ethnic violence and group threat theory. Relative deprivation theory examines the effect of poverty, unemployment and inequality on the collective psyche of poor South Africans. The theory of ethnic violence explains states that violent actions occur when perpetrators are reasonably sure that the authorities, through law enforcement agents, will not protect victims and the latter are incapable of fighting back. Group threat theory postulates that dominant groups are likely to engage in hostile action if it perceives its social position is threatened by a minority group (King, 2007: 1227).

Regarding institutional explanations, the state is said to have a monopoly on violence, but also has a duty to protect people's rights. This means, the actions of the state, through its agents, is of paramount importance. As such, institutional explanations for xenophobia include the attitude and behaviour of politicians and civil servants, the gap between written policy and policy in practice and state agencies' treatment of foreigners. In the latter respect, poor treatment of asylum-seekers by Department of Home Affairs officials and police tearing up valid papers and deporting "illegal" migrants (Crush, 2008: 14), are illustrative. 
Harris' (2001, 2002) scapegoating, isolation and bio-cultural hypotheses, which explain xenophobia in the South African context, are briefly discussed. These hypotheses, which explain xenophobia in the South African context, are largely drawn from the broad sociocultural, structural and institutional explanations highlighted in the preceding section.

\section{Scapegoating hypothesis}

According to Harris (2002: n.p.), the scapegoating hypothesis derives from sociological theory and is based on the theory of relative deprivation. In the midst of unemployment, poverty and inequality, the post-apartheid era has raised expectations of most South Africans to live better lives after decades of deprivation. For many, these expectation have not materialised fast and substantially enough and brings to the limelight uneven distribution of resources wealth that breeds discontent. Given this background, hostility towards foreigners can be explained by competition for scarce resources such as housing, education, health care and employment as they create a "frustration-scapegoat" embodied in foreign migrants. The hypothesis combines socio-economic factors with a psychological explanation of deprivation, which arises from a subjective feeling of discontent based on the belief that one is getting less than one feels entitled to (Harris, 2002: n.p.). This means citizens compare themselves to non-citizens with respect to access to the scarce resources and when they see themselves as relatively deprived they invent a "frustration-scapegoat. Social ills and citizens" personal frustration and anger with life's difficulties are then directed at the "frustration-scapegoat", who takes the blame. Drawing on the theories of aggression and frustration, a link is established between relative deprivation, xenophobia and collective violence. There is, however, little evidence behind claims that non-nationals represent a significant drain on the state's financial resources. Although the scapegoating theory is plausible, it is neither able to explain why the foreign black, specifically, must be the scapegoat for unemployment, poverty and deprivation nor why nationality is the criterion of scapegoating (Harris, 2002).

\section{Isolation hypothesis}

The isolation theory is based on the belief that apartheid-induced internal isolation of South Africans of different racial groups from each other and isolation from the international community resulted in diminished ability of citizens to accommodate and tolerate differences (Harris, 2002). This means South Africa's gaining of independence in 1994, which made it part of the international community and opened the floodgates for millions of migrants to enter the country, was bound to produce negative interaction outcomes. Simply put, the isolation hypothesis for xenophobia is that being different is threatening and hostility towards black foreigners is based on their being foreign, unknown and different.

Powerful as the isolation hypothesis is, Harris (2002) points out that it does not explain why 'the unknown' produces anxiety and why it culminates in aggression. The hypothesis, however, offers a nexus between South African blacks' enforced internal isolation from other racial groups and external isolation from the wider international community, including African countries, and their suspicion of and hostility towards foreign blacks. Isolation has left many black South Africans with very little or no knowledge about the rest of the continent. Consequently, in daily interactions, many South Africans tend to portray South Africa as if it is located in a different continent. 


\section{Bi-cultural hypothesis}

As pointed our earlier, xenophobia is not uniformly applied to all foreigners. While citizens of African countries are selectively and rampantly at the receiving end of black South Africans' hostility (HRF, 2009), in the literature, there are no reported incidents of white foreigners, some who are in South Africa illegally, being targets of xenophobia. Similarly, very few Asians have been targets (Bekker, 2010: 34). This selective and unequal targeting of foreigners is explained by the bicultural hypothesis, which "locates xenophobia at the level of visible difference, or otherness, that is, in terms of physical biological factors and cultural differences exhibited by African foreigners in the country" (Harris, 2002: n.p.) such as physical features or specific biological-cultural features, comportment and inability to speak one of the local languages.

Biological-cultural signifiers are implicated in xenophobia as they make it easy to identify specific categories of foreigners for violent action. However, it is problematic to rely on biological-cultural markers of difference to explain otherness and consequent asymmetrical xenophobia because these signifiers also exist for whites and Asians, who are relatively less at risk of xenophobic violence as African blacks.

Individually and collectively, however, the three hypotheses do not sufficiently explain why xenophobia in South Africa is specifically directed at black foreigners. It is suggested that selective xenophobia is better explained by a nationalistic mode championed by the media that portrays foreigners exclusively in a negative light. In this respect, the main characteristics of print media are: negative references to migrants and immigrants, un-analytical, simplistic approach, referring to migrants as "illegal immigrants" and stereotyping ("job stealers", "criminals" and "illegals"). In this light, Crush (2008: 42) states that: "several research studies have shown how the media has uncritically reproduced xenophobic language and statements, time and time again. The media has certainly been complicit in encouraging xenophobic attitudes among the population." Smith (2009: 29) indicates that research has found convincing evidence that leading up to and including May 2008, the South African print media was xenophobic.

While admitting that the causes of xenophobia are complex and multi-faceted, Pillay (cited in Hadland, n.d.: 14-16), identifies three factors, namely: relative deprivation, South African exceptionalism and exclusive citizenship, as underlying causes of xenophobia. Relative deprivation, as explained earlier, focuses on the nexus between socio-economic factors such as poverty, inequality and unemployment. South African exceptionalism refers to South Africa's apartheid history creating a sense of superiority and uniting both black and white South Africans against other Africans who are perceived as lacking cultural and economic value. The third factor, exclusive citizenship, relates to inclusive or exclusive tendencies engendered by nationalism. In the main, the post-1994 South African state has been exclusive in the sense that while South Africa sees itself as a "rainbow nation", some South Africans tend to look down on the rest of Africa in spite of African countries having played a critical role in the country's liberation struggle and opening their doors to South African businesses after majority rule. President Zuma's derogatory statement in November 2013, while defending the introduction of e-tolls between Johannesburg and Pretoria epitomises, par excellence, South Africa's condescension and belittling of other African countries: "We can't think like Africans in Africa, generally. This is Johannesburg. It's not some national road in Malawi". 
To explain South African exceptionalism, according to Neocosmos (2006: 12), nationalism is an important component of xenophobia. In developmental terms, South Africans, irrespective of racial group, tend to see the country as being in the same league as countries in Southern Europe and Latin America, while the rest of Africa is thought to be "characterised by primitivism, corruption, authoritarianism, poverty and 'failed states"', whose citizens are interested in benefiting from South Africa's resources and wealth at the expense of its citizens (Harris, 2001). This, undoubtedly, feeds into the xenophobia narrative.

\section{Conclusion}

For South Africans and the government, in particular, to effectively deal with attacks against mainly black, non-South African immigrants, it is essential to identify and name the new monster the country is faced with. The importance of an appropriate nomenclature for the attacks phenomenon cannot be underestimated. A good understanding of the causes, explanations and theories surrounding the attacks is also necessary. These are the key research issues addressed in this article. Different labels have been used in characterising the rampant attacks, including pure criminality, Afro-phobia/Negrophobia, xenophobia and outright racism. As the analyses show, while there are grounds for each label, the bulk of empirical studies suggest widespread acceptance of the term xenophobia. Regarding causes of the attacks, various explanations have been advanced: economic/material, social/socio-political, cultural stereotyping, lack of political leadership, denialism and "naked criminal activity", and "violent entrepreneurship", among others. "Frustration-scapegoating", isolation and bicultural hypotheses are also discussed. No single or simple explanation xenophobia is can be identified because of its complexity. It is recommended that solutions be found to the perennial problem of xenophobia. Since they cannot be simple, the process needs to involve key stakeholders such as the Department of Home Affairs, South African government and governments of sending countries, recognised South African civil society groups, immigrant associations; international organisations such as relevant organs of the United Nations and the African Union, African regional economic blocs such as the Southern African Development Community, Economic Community of African States, East African Community and others, researchers, research entities such as the Southern African Migration Programme and non-governmental organisations, among others.

\section{References}

Adjai, C. \& Lazaridis, G. 2013. Migration, xenophobia and the new racism in post-apartheid South Africa. International Journal of Social Sciences, 1(1): 192-205.

Aremu, J.O. 2013. Responses to the 1983 expulsion of aliens from Nigeria: a critique. African Research Review: An International Multidisciplinary Journal, 7(3): 340-352. July.

Aremu, J.O. 2014. Expulsion of Nigerian immigrants community from Ghana in 1969: causes and impact. Developing Country Studies, 4(10): 176-186.

Bekker, S. 2010. Explaining violence against foreigners and strangers in urban South Africa: outburst during May and June 2008. In Yusuf, A.A. (ed.), The African Yearbook of International Law. Leiden: Brill Publishers, pp.125-149. 
Charman, A. \& Piper, L. 2012. Xenophobia, criminality and violent entrepreneurship: violence against Somali shopkeepers in Delft South, Cape Town, South Africa. South African Review of Sociology, 43(3): 82-105.

Crush, J. (ed.). 2008. The perfect storm: The realities of xenophobia in contemporary South Africa. IDASA and Southern African Migration Project. Migration Policy Series, No 50. 1-67.

Crush, J. \& Ramachandran, S. 2014. Xenophobic violence in South Africa: denialism, minimalism, realism. Southern African Migration Programme (SAMP). International Migration Research Centre (IMRC). Migration Series no. 66. http://www.queensu.ca/samp/sampresources/samppublications/policyseries/Acrobat66 .pdf [Accessed: 10 September 2015].

Davis, A. 2010. Fear, dislike and hate: what constitutes xenophobia? An analysis of violence against foreigners in De Doorns, South Africa November, 2009. A minor dissertation submitted in partial fulfillment of the requirements for the award of the degree of Masters of Philosophy in Development Studies. Faculty of the Humanities, University of Cape Town.

Dodson, B. 2010. Locating Xenophobia: Debate, Discourse and Everyday Experience in Cape Town, South

http://ir.lib.uwo.ca/cgi/viewcontent.cgi?article=1361\&context=geographypub

Africa.

[Accessed: 10 September 2015].

Everatt, D. n.d. South African civil society and xenophobia: synthesis. http://ccs.ukzn.ac.za/files/Synthesis\%20Overview\%20\&\%20Prospects, \%20Summary \%20of\%20Findings\%20\&\%20Recommendations.pdf [Accessed: 10 September 2015].

Fauvelle-Aymar, C. \& Segatti, A. 2011. People, space and politics: an exploration of factors explaining the 2008 anti-foreigner violence in South Africa. In Landau, L. (ed.). Exorcising the Demons Within: Xenophobia, Violence and Statecraft in Contemporary South Africa. Johannesburg: Wits University Press, pp.56-88.

Hågensen, L. 2014. Understanding the causes and nature of xenophobia in South Africa: a study of De Doorns. Thesis presented in partial fulfillment of the requirements for the Master of Arts (International Studies) in the Faculty of Arts and Social Sciences at Stellenbosch University, Cape Town.

Harris, B. 2002. Xenophobia: A new pathology for a new South Africa? In Hook, D. \& Eagle, G. (eds.), Psychopathology and Social Prejudice. Cape Town: University of Cape Town Press, pp.169-184.

Human Rights First, 2011. Combating xenophobic violence: a framework for action.

https://www.humanrightsfirst.org/wp-content/uploads/pdf/UNHCR_Blueprint.pdf [Accessed: 10 September 2015].

Kersting, N. 2009. New nationalism and xenophobia in Africa - a new inclination? Africa Spectrum, 44(1): 7-18.

King, R.D. 2007. Group threat and social control: race, perceptions of minorities and the desire to punish. Social Forces, 85(3): 1255-1280. 
Gqola, P.D. 2008. Brutal inheritances: echoes, negrophobia and masculinist violence. In Hassim, S., Kupe, T. \& Worby, E. (eds.), Go Home or Die Here: Violence, Xenophobia and the Reinvention of Difference in South Africa. Johannesburg: Wits University Press.

Landau, L.B. (ed.). n.d. Exorcising the Demons within. Xenophobia, Violence and Statecraft in Contemporary South Africa. Tokyo, New york, Paris: United Nations University Press.

Mbeki, T. 2008. Speech at a tribute to the victims of the May 2008 attacks. Pretoria, 3 July 2008.

McKnight, J. 2008. Through the fear: a study of xenophobia in South Africa's refugee system. Journal of Identity and Migration Studies, 2(2): 18-42.

Misago, J.P., Landau, L.B. \& Monson, T. 2008. Tensions, territory and terror: understanding violence against foreigners in South Africa. Research conducted with the support of The International Organization for Migration (IOM), The Atlantic Philantropies and Oxfam UK. Forced Migration Studies Programme. University of the Witwatersrand.

Mngxitama, A. 2009. We are not all like that: race, class and nation after apartheid. In Hassim, S, Kupe, T. \& Worby, E. (eds.), Go Home or Die Here: Violence, Xenophobia and the Reinvention of Difference in South Africa. Johannesburg: Wits University Press.

Neocosmos, M. 2006. From "foreign natives" to "native foreigners": Explaining Xenophobia in Post-apartheid South Africa. Dakar: CODESRIA.

Nyamnjoh, F.B. 2006. Insiders and Outsiders: Citizenship and Xenophobia in Contemporary Southern Africa. London: Zed Books Ltd.

Petros, A., Airhihenbuwa, C.O., Simbayi, R. \& Brown, B. 2006. HIV/Aids and "othering” in South Africa: the blame goes on. Cultural Health and Sexuality, 8(1): 67-77.

Pollmann, M. 2015. Despite recent efforts, hate speech and racial discrimination continues to plague Japan. The Diplomat, July 24 2015. http://thediplomat.com/2015/07/japansxenophobia-problem/ [Accessed: 12 September 2015].

Polzer, T. \& Takabvirwa, K. 2010. “Just crime?” Violence, xenophobia and crime: discourse and practice. SA Crime Quarterly, 33: 1-10.

Sharp, J. 2008. "Fortress SA": xenophobic violence in South Africa. Anthropology Today, 24(4): 1-3.

Smith, M.J. 2009. The right to respond: a meta-review of the role of the South African media's coverage of xenophobic violence prior to and including May 2008. http://www.atlanticphilanthropies.org/sites/all/modules/filemanager/files/14_Media_c .pdf [Accessed: 10 September 2015].

Solomon, H. \& Kasaka, H. n.d. Xenophobia in South Africa: reflections, narratives and recommendations. Southern African Peace and Security Studies, 2: 2.

Tafira, K.M. 2011. Is xenophobia racism? Anthropology Southern Africa. 34(3\&4):.114-121.

Tumuhairwe, C. 2012. The effect of Idi Amin's expulsion of the Asian community in Uganda on the economic and social development of the country. Working Paper No 2012/37. Maastricht School of Management. http://www.msm.nl/resources/uploads/2014/02/MSM-WP2012-37.pdf [Accessed: 10 September 2015]. 
White Papers of Hate, 2013. Centrale Magazine - 13. http://www.centrale.be/wpcontent/uploads/2015/03/Mag-387-Anti-Semitism-In-Europe.pdf [Accessed: 10 October 2015]. 